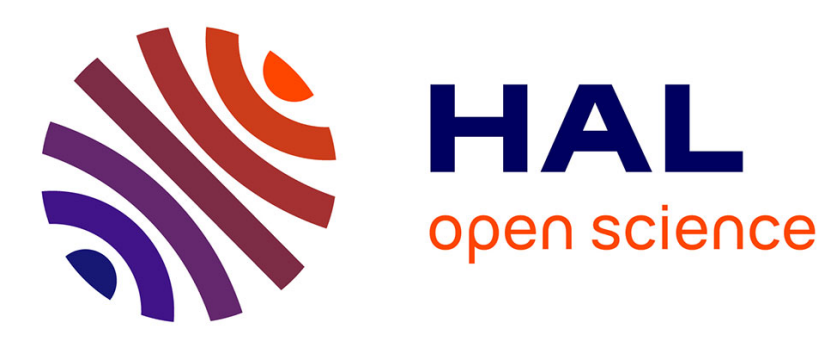

\title{
Influence of phenol on glucose degradation during supercritical water gasification
}

Elsa Weiss-Hortala, Andrea Kruse, Christina Ceccarelli, Radu Barna

\section{To cite this version:}

Elsa Weiss-Hortala, Andrea Kruse, Christina Ceccarelli, Radu Barna. Influence of phenol on glucose degradation during supercritical water gasification. Journal of Supercritical Fluids, 2010, 53 (1-3), pp.42 - 47. 10.1016/j.supflu.2010.01.004 . hal-01768961

\section{HAL Id: hal-01768961 https://imt-mines-albi.hal.science/hal-01768961}

Submitted on 17 Apr 2018

HAL is a multi-disciplinary open access archive for the deposit and dissemination of scientific research documents, whether they are published or not. The documents may come from teaching and research institutions in France or abroad, or from public or private research centers.
L'archive ouverte pluridisciplinaire HAL, est destinée au dépôt et à la diffusion de documents scientifiques de niveau recherche, publiés ou non, émanant des établissements d'enseignement et de recherche français ou étrangers, des laboratoires publics ou privés. 


\section{Influence of phenol on glucose degradation during}

\section{supercritical water gasification}

Elsa Weiss-Hortala*1,2 ${ }^{1,}$ Andrea Kruse ${ }^{3}$, Christina Ceccarelli ${ }^{3}$, Radu Barna ${ }^{1,2}$

${ }^{1}$ Université de Toulouse; Mines Albi; CNRS; Campus Jarlard; F-81013 ALBI cedex 09, FRANCE

${ }^{2}$ Ecole des Mines d'Albi, Centre RAPSODEE, Campus Jarlard, F-81013 ALBI, FRANCE

${ }^{3}$ Institute for Technical Chemistry, Division of Chemical-Physical Processing, Karlsruhe Institute of Technology (KIT), Hermann-von-Helmholtz-Platz 1, 76344 Eggenstein-Leopoldshafen, GERMANY

${ }^{*}$ Corresponding author - Phone number: 33 (0)5 63493145 - Fax: 33 (0)5 63493243

E-mail address: elsa.weiss@mines-albi.fr

In a continuous tubular reactor, the gasification efficiency of solutions containing phenol, glucose or the two pure compounds are conducted in presence of an alkaline catalyst. The comparison of the gas yields showed that presence of phenol in a glucose solution decreased dramatically the conversion efficiency of the solution at the comparable operating conditions (pressure, temperature, flow rate, catalyst concentration).

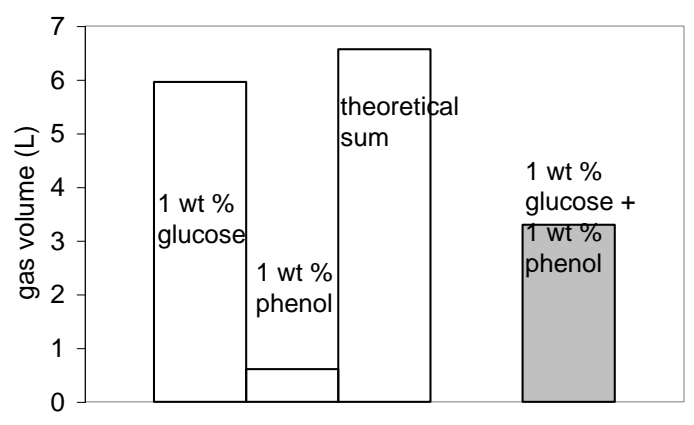




\title{
Influence of phenol on glucose degradation during
}

\section{supercritical water gasification}

Elsa Weiss-Hortala* ${ }^{1,2}$, Andrea Kruse $^{3}$, Christina Ceccarelli ${ }^{3}$, Radu Barna $^{1,2}$

${ }^{1}$ Université de Toulouse; Mines Albi; CNRS; Campus Jarlard; F-81013 ALBI cedex 09, FRANCE

${ }^{2}$ Ecole des Mines d'Albi, Centre RAPSODEE, Campus Jarlard, F-81013 ALBI, FRANCE

${ }^{3}$ Institute for Technical Chemistry, Division of Chemical-Physical Processing, Karlsruhe Institute of Technology (KIT), Hermann-von-Helmholtz-Platz 1, 76344 Eggenstein-Leopoldshafen, GERMANY

* Corresponding author - Phone number: 33 (0)5 63493145 - Fax: 33 (0)5 63493243

E-mail address: elsa.weiss@mines-albi.fr

\begin{abstract}
Biomass is the ideal alternative renewable energy that might help decrease $\mathrm{CO}_{2}$ emissions. Super Critical Water Gasification (SCWG) is a recent treatment method which is still being developed as regards wet biomass. Above its critical point, water has specific properties and is able to convert wet biomass into gas, and especially into hydrogen. In order to propose a general reaction scheme of the SCWG as regards the lignocellulosic biomass conversion, the interactions between lignin and cellulose must be highlighted. Lignocellulosic biomass could be modelled with phenol (substitute for lignin) and glucose (substitute for cellulose).

In a continuous flow tubular reactor, the gasification of solutions containing phenol and glucose or either of the two pure compounds is more efficiently performed when in presence of an alkaline catalyst. The comparison of global parameters, such as the Total Organic Carbon content (TOC), the composition of the liquid product phase (glucose, phenol...), the volume and composition of the gas phase $\left(\mathrm{H}_{2}, \mathrm{CO}_{2}, \mathrm{CH}_{4} \ldots\right)$, showed that a small quantity of phenol in a glucose solution dramatically decreased the efficiency of the solution's conversion.
\end{abstract}

Keywords: supercritical water gasification, phenol, glucose, hydrogen production 


\section{Introduction}

Nowadays, researchers are getting more involved in the field of renewable or supposedly renewable forms of energies: solar power, wind energy, biogas, synthetic gas... with view to replace fossil energies and decrease carbon dioxide emissions that are ensued from fossil compound processing operations. With consideration of these two points, biomass is the ideal alternative energy, with a carbon dioxide balance close to zero. Most of the currently used techniques are efficient with dry biomass (pyrolysis for example). On the contrary, Super Critical Water Gasification (SCWG) is a recent treatment method which is still being developed [1], and that allows wet biomass to be used, even with a natural water content of up to $80-90 \%$.

The principle is to convert wet biomass into gas, using high temperatures and pressures. Above the critical point $\left(22.1 \mathrm{MPa}\right.$ and $\left.374^{\circ} \mathrm{C}\right)$, water has specific properties and is able to convert carbon from the biomass into methane and/or carbon dioxide. During this process, hydrogen that was bonded to biomass could also be transformed into dihydrogen. At the present time, hydrogen seems to be the best alternative source of energy thanks to its high energy potential and eco-friendly properties, but it has to be produced in a sustainable way. Different technologies for $\mathrm{H}_{2}$ production are under development.

Above its critical point, water is a monophasic system [2], and its physico-chemical properties are no longer the same when it is liquid [3, 4]. Generally speaking, supercritical fluids are interesting because they form a unique phase; their diffusivity is close to that of gases and their density could be easily adjusted to the desired values [5]. SCW media are very reactive because they efficiently hydrolyse organic compounds [6-8]. At low densities, SCW is a poor solvent for ionic species like inorganic salts [9], but it is completely miscible with many organic compounds and gases [8], allowing the precipitation of inorganic salts on the one 
hand, and homogenous reaction processes between gases and organic compounds on the other hand. Reactions in supercritical water could be catalysed by acid or base $[8,10]$ or initiated by free radicals [11].

Biomass reacts with water and forms hydrogen and carbon dioxide in a steam reforming reaction [12, 13] following Eq. 1. Both Water-Gas Shift reaction (Eq. 2, WGS) and methanation (Eq. 3) are used to determine the composition of the gas.

$$
\begin{aligned}
& \mathrm{CH}_{x} \mathrm{O}_{y}+(2-y) \mathrm{H}_{2} \mathrm{O} \leftrightarrow \mathrm{CO}_{2}+\left(2-y+\frac{x}{2}\right) \mathrm{H}_{2} \\
& \mathrm{CO}+\mathrm{H}_{2} \mathrm{O} \leftrightarrow \mathrm{CO}_{2}+\mathrm{H}_{2} \\
& \mathrm{CO}+3 \mathrm{H}_{2} \leftrightarrow \mathrm{CH}_{4}+\mathrm{H}_{2} \mathrm{O}
\end{aligned}
$$

Even water is very reactive, chemical kinetics is a limitative factor in the development of a technical process (1). Sometimes, char and/or tar could be produced during the process [13]. Catalysts are used to increase reaction rates and support some reaction pathways, such as the WGS by alkaline salts [13-15]. After cooling and depressurising sequences, both liquid and gas phases are analysed.

Most studies are published on the SCWG of glucose [11-13, 16-20], which is an intermediate compound of cellulose decomposition [21-22]. Some recent studies show that both the presence of lignin in the feedstock and operating conditions have an influence on the gasification efficiency [23-26] and that the lignin seems to modify the conversion efficiency of the carbohydrate conversion $[23,25,27]$. In order to propose a general reaction scheme of the SCWG for lignocellulosic biomass, the interactions between these two compounds must be highlighted. In this paper, lignocellulosic biomass was modelled by glucose as substitute for cellulose and phenol for lignin. In our experimental approach, we used two representative molecules. Glucose is the hydrolysis product of cellulose. Phenol is easily obtained in SCW by the degradation of guaiacol [28] and can be considered as one of the structural building 
bricks of lignin. We have decided to use phenol, the simplest molecule presenting the Ar-OH structure, as a substitute for lignin.

The lignin molecule is a complex arrangement of aromatic rings. In the different molecular forms of lignin that have been proposed, guaiacol (o-methoxy-phenol) is one of the most abundant aromatic rings containing hydroxyl and methoxy substituent. Di Leo et al. [29] have noted that guaiacol quickly disappears during SCWG and can be substituted by its reaction products, e.g. phenol. During the hydrothermal degradation of lignin, phenol and different substituted phenols are formed as intermediate products of lignin gasification [24, 30]. Phenol is also a widely encountered industrial pollutant (oil, painting, pesticides, colouring agents and pharmaceutical industries), which is difficult to eliminate from wastewater [31, 32]. Phenol's oxidation in supercritical water (SCWO) is a very big issue in many publications. SCWO of phenol was performed in batch or continuous flow tubular reactors [33-37] in various experimental conditions: temperatures from $300-630^{\circ} \mathrm{C}$, pressure range from $21-31$ $\mathrm{MPa}$, oxygen excess, various water densities and reaction times. Different global kinetic models have been proposed for phenol degradation, almost pseudo first order for phenol; in general, the oxidation kinetic is considered as an Arrhenius type process. Water density in the mixture seems to play a complex role. In general, with the decrease of water density the main mechanisms change from heterolytic (ionic) to homolytic (radical) as a result of the concomitant change of the dielectric constant of water, of ion product of water $\mathrm{Kw}$, of phenol dissociation, of diffusion coefficients and rates of the diffusion controlled reactions. The experiments showed that water inhibits the reaction rate at low densities and high temperatures and it accelerates the rate at lower temperatures and higher water densities.

Different mechanisms for phenol SCWO have been published [33-35, 38], and among the characterised products of the reaction, the main ones in the liquid phase are phenoxyphenols, biphenol, dibenzofuran, acids (oxalic, acetic, benzoic, salicylic...). The gasification of phenol 
in supercritical water was also studied, showing a relatively slow degradation, yet more efficient when using an Ni catalyst in a quartz reactor [28-29].

Alkali salts are used as substitute for inorganic ("ash") components of natural biomass. It was shown that both $\mathrm{KHCO}_{3}$ and natural inorganic components act as catalysts in the water-gas shift reaction $[1,11]$. The addition of the salt enables the model system and real biomass to be more efficiently compared.

\section{Materials and methods}

\subsection{Continuous flow reactor and operating conditions}

Experiments were performed in a continuous flow tubular reactor (Fig. 1) made of Inconel 625. It is an $18 \mathrm{~m}$-long helix with an internal diameter of $1.6 \mathrm{~mm}$ and an external diameter of $6.35 \mathrm{~mm}$. The volume of the reaction zone is $36.19 \mathrm{~mL}$. The electric heating was controlled by a thermocouple on the external surface of the reactor. The GraphWorX32 module of the Genesis32 Software program supplied by ICONICS was used to control and monitor the temperatures. The solution was injected into the reactor with a membrane pump, supplied by LEWA (Type EL1). After cooling, the product mixture was expanded to ambient pressure by a back-pressure regulator.

In all experiments, $\mathrm{KHCO}_{3}$ (Roth Company, 99.5\% purity) was used as catalyst at $0.2 \mathrm{wt} \%$. The pressure was kept constant at $25 \mathrm{MPa}$. The working temperatures were of 400, 450, 500 and $550{ }^{\circ} \mathrm{C}$. The flow rate was set between 0.9 and $3.8 \mathrm{~kg} \mathrm{~h}^{-1}$. Considering the reactor volume of $36.19 \mathrm{~mL}$ and the volumic flow rate at the temperature and pressure in the reactor, the corresponding residence times were of 0.25 down to $0.06 \mathrm{~min}$. The concentration of glucose $\left(\mathrm{C}_{6} \mathrm{H}_{12} \mathrm{O}_{6}, \mathrm{H}_{2} \mathrm{O}\right.$ Monohydrate, Merck) or phenol $\left(\mathrm{C}_{6} \mathrm{H}_{6} \mathrm{O}\right.$, Merck, $99 \%$ purity) varied from 0.25 to 2 wt $\%$. 
The experimental error, estimated by repeated experiments in the same experimental conditions, is in the range of $\pm 10 \%$ of the given data.

\subsection{Analyses}

After cooling, gas and liquid phases were analysed. No solid phase was observed in these operating conditions. After 30 and 60 minutes of stable state of the reactor, gas and liquid samples were taken for analysis. The obtained results were an average of the analysed samples. To compare the efficiency of the conversion, the only comparison of gas volume or liquid mass is not pertinent, particularly in case of different flow rates. In the outflow, a normalised gas yield ( $\mathrm{N}$ gas yield), calculated by the volume of gas and the weight of the liquid obtained after the 60 min steady state of the reactor, was defined:

$$
N \text { gas yield }=\frac{\text { gas volume }}{\text { liquid weight }} \text { in } \mathrm{L} \mathrm{kg}^{-1}
$$

The mass error is $0.1 \mathrm{~g}$ and the gas volume error is $10 \%$.

\subsubsection{Liquid phase}

The efficiency of the organic compounds' conversion was estimated by measuring the Total Organic Carbon (DIMATOC ${ }^{\circledR} 2000$ ) with an error of $2 \%$. To represent this efficiency, the TOC removal will be calculated as follows:

$$
\text { TOC removal }=\frac{\left(T O C_{\text {initial }}-T O C_{\text {final }}\right)}{T O C_{\text {initial }}} \times 100
$$

Residual phenols (phenol and substituted phenols) representing synthesised and/or undecomposed phenol as well as glucose and fructose were also quantified in the liquid phase by using a colorimetric test from Hach-Lange (LCK 346 Phenols), a specific enzymatic test and a UV-method supplied by Roche. The error in the analysis of glucose/fructose concentration was $0.5 \%$ and $5 \%$ for phenol. 
In addition, UV-Vis (DR 5000, Lange-Hach) measurements are conducted with selected samples. The results show the presence of phenols and other aromatic compounds with a single aromatic system. No adsorption at longer wavelength was detected, therefore no hint for polyaromatic systems is found.

After the phenol-glucose mixture reaction, the GC-MS ${ }^{1}$ analysis of the selected samples not only shows phenol presence but also that of alkyl-phenols (mainly methylphenols) in the product mixture.

\subsubsection{Gas phase}

An HP-6890A Series Gas Chromatograph was used to analyse the gas, and the injected volume was $100 \mu \mathrm{L}$. Two columns (80/100 Hayesep and 60/80 Molesieve 5A) and two kinds of detectors were placed in series so as to determine the composition and quantification of the gas. The main gases to be quantified were $\mathrm{H}_{2}, \mathrm{CO}_{2}, \mathrm{CH}_{4}, \mathrm{CO}$ and some light hydrocarbons $\left(\mathrm{C}_{2} \mathrm{H}_{6}, \mathrm{C}_{3} \mathrm{H}_{8} \ldots\right)$.

\section{Results and discussion}

Sinağ et al. demonstrated the effect of alkaline salt on glucose gasification in this reactor [39], they concluded that $\mathrm{KHCO}_{3}$ improved gas generation and decreased the amount of furfural in the liquid phase.

\subsection{Glucose solutions}

\footnotetext{
${ }^{1}$ The analysis procedure includes Solid Phase Extraction and GC-MS processing of the obtained methanol solution. The implemented procedure is detailed in A. Kruse, P. Bernolle, N. Dahmen, E. Dinjus, P. Maniam, Hydrothermal gasification of biomass: consecutive reactions to long-living intermediates. Energy \& Environmental Science (2009), in press.
} 
The influence of the glucose concentration was studied in the range of $0.25-2$ wt $\%$ at 25 $\mathrm{MPa}, 500^{\circ} \mathrm{C}$ and with a flow rate of $1.385 \mathrm{~kg} \mathrm{~h}^{-1}$ (residence time equals to $0.1624 \mathrm{~min}$ ). Glucose was totally removed from the solution $\left(<0.003 \mathrm{mg} \mathrm{L}^{-1}\right.$, not shown), meaning that molecules completely react with supercritical water in the considered operating conditions. Moreover, fructose was also quantified and the values were less than $0.01 \mathrm{mg} \mathrm{L}^{-1}$. These experimental results are in accordance with the literature $[12,20,40]$. During the continuous process, no solid particle was observed.

Fig. 2 shows that, in these operating conditions, the normalised gas yield (Eq. 4) linearly increases along with the glucose concentration in the solution. For a glucose concentration in the range of $0.25-2 \mathrm{wt} \%$, this linear behaviour means that catalyst concentration is not kinetically limitative. This linear behaviour could also indicate that the conversion's efficiency, i.e. mole distribution between the gas and the liquid phases, is nearly the same in all experiments. The evolution of TOC and residual phenol of the liquid phase as function of glucose concentration is also linear (not shown). An increasing linear profile for the TOC indicates that the mineralisation of organic compounds is independent from the concentration in the investigated range. As seen in the literature, phenol is an intermediate product of glucose degradation $[11,19,20,41]$. The concentration of residual phenol in the liquid outflow linearly increases with glucose concentration, meaning that the ratio between the phenol concentration and the initial glucose concentration is the same in all experiments. Phenol concentration is a balance between phenol formation from glucose and phenol conversion during SCWG. This linear profile could indicate that rates and reaction mechanisms are similar in all experiments. As regards values, TOC removal was close to $90 \%$ (between 88 and 90\%) in each experiment, indicating that mineralisation was efficient in these operating conditions. 
Fig. 3 represents the volume percentage of the main gas $\left(\mathrm{H}_{2}, \mathrm{CO}_{2}, \mathrm{CH}_{4}\right.$ and $\left.\mathrm{CO}\right)$ in the total volume as function of glucose concentration. The composition of the gas is of about 50 vol.\% $\mathrm{H}_{2}, 40$ vol.\% $\mathrm{CO}_{2}, 10$ vol.\% $\mathrm{CH}_{4}$ and 1 vol.\% $\mathrm{CO}$. These values are in the same order of magnitude as those obtained in the literature under various operating conditions $[12,16,20]$. Hydrogen is the main compound in the gas phase. Of course, the presence of the catalyst decreases the amount of $\mathrm{CO}$, and therefore the WGS reaction is promoted. Fig. 3 shows that, when glucose concentration increases, the proportion of $\mathrm{H}_{2}$ slightly decreases and the proportion of $\mathrm{CO}_{2}$ slightly increases. This phenomenon could be due to a difference between the kinetics of the reactions. Taking the general and total reaction scheme following Eq.6 into account:

$\mathrm{C}_{6} \mathrm{H}_{12} \mathrm{O}_{6}+6 \mathrm{H}_{2} \mathrm{O} \leftrightarrow 6 \mathrm{CO}_{2}+12 \mathrm{H}_{2}$

the part of hydrogen should be doubled compared to carbon dioxide volume. The different ratios of the gases indicate that the reaction is not complete, even if glucose has totally disappeared, and even if the kinetics of degradation or other consecutive reactions seem to be different for the intermediate products. In other words: hydrogen reacts with the intermediate products by hydrogenation and this reaction has a higher reaction order than glucose degradation.

\subsection{Phenol solutions}

According to literature, the reaction rate of phenol gasification in a batch reactor is low without any $\mathrm{Ni}$ catalyst, and a temperature of $700^{\circ} \mathrm{C}$ leads to a complete reaction of phenol in a short time compared to that of $600^{\circ} \mathrm{C}[29]$.

\subsubsection{Influence of flow rate}

As regards phenol solutions, the influence of flow rate (or residence time) was studied in the range of $0.9-3.8 \mathrm{~kg} \mathrm{~h}^{-1}$ (residence time equals to $0.23-0.06 \mathrm{~min}$ ) for a phenol concentration of 
1 wt $\%$ (corresponding to $10 \mathrm{~g} \mathrm{~L}^{-1}$ ) at $25 \mathrm{MPa}$ and $500^{\circ} \mathrm{C}$. Fig. 4 shows that the conversion of phenol is not efficient (less than 50\%). Contrary to glucose solutions, the reactivity of phenol in supercritical water is low in these operating conditions. The experiments performed by DiLeo et al. on phenol solutions with or without Ni catalyst $[28,29]$ showed that the relation between water density and phenol concentration has an influence on the conversion's efficiency. It was concluded that an optimal water density $\left(0.079 \mathrm{~g} \mathrm{~mL}^{-1}\right)$ might exist for homogeneous SCWG of phenol at $600^{\circ} \mathrm{C}$ with an Ni catalyst [28]. It was also demonstrated that phenol removal was only of $25 \%$ without any $\mathrm{Ni}$ catalyst while the value reached $93 \%$ with an Ni catalyst in the same period of 10 min [29]. For all parameters (TOC, phenol and relative gas yield) as function of residence time, the profiles of the curves show an abrupt increase or decrease between the lower residence time and the intermediate one, and the values of the next points are quite similar. According to literature, this low conversion is a consequence of the short reaction times in the experiments hereby presented. The composition of the gas phase is quite stable at the different flow rates, especially as regards $\mathrm{H}_{2}(45 \%)$ and $\mathrm{CO}_{2}(32 \%)$. With an $\mathrm{Ni}$ catalyst, the ratio between $\mathrm{H}_{2}$ and $\mathrm{CO}_{2}$ is close to two in optimised conditions [28].

\subsubsection{Influence of temperature}

To study the influence of temperature in the range of $400-500^{\circ} \mathrm{C}$ at constant pressure, it has to be considered that a change in the temperature not only influences the reaction rate with a continuous activation energy but also changes the water density [28]. As regards pure water, density equals to $0.166 \mathrm{~g} \mathrm{~mL}^{-1}$ at $400^{\circ} \mathrm{C}, 0.109 \mathrm{~g} \mathrm{~mL}^{-1}$ at $450^{\circ} \mathrm{C}$ and $0.089 \mathrm{~g} \mathrm{~mL}^{-1}$ at $500^{\circ} \mathrm{C}$. Fig. 5 shows the residual phenol as function of the reactor's temperature, for the lowest residence time. The quantity of phenols decreases when the temperature increases. At $500^{\circ} \mathrm{C}$, phenol removal reaches $52 \%$ compared to $12 \%$ at $450^{\circ} \mathrm{C}$. This means that higher temperatures promote the reactivity of phenols in supercritical water. Temperature also favours TOC 
removal, increasing from $1 \%\left(400^{\circ} \mathrm{C}\right)$ to $9 \%\left(450^{\circ} \mathrm{C}\right)$ and up to $50 \%$ at $500^{\circ} \mathrm{C}$ (values not shown on Fig. 5).

\subsection{Glucose and phenol solutions}

The first objective is to check the influence of phenol on glucose degradation. The gas volume from the solutions containing only one compound (1 wt \%) was compared to that of mixture solutions ( 1 wt $\%$ of each compound). With this kind of representation, the degradation process of both components will be independent if the values for the mixture are the sum of the other two values. The gas volume of the three solutions and the theoretical sum is shown in Fig. 6 with a flow rate of $1.385 \mathrm{~kg} \mathrm{~h}^{-1}$, at $\mathrm{T}=500^{\circ} \mathrm{C}$ and observations are the same with the other flow rates. The theoretical sum of gas volumes is higher than the experimental gas volume obtained from the mixture solution: the simultaneous presence of the two compounds in the mixture decreases the production of gas. For example, the gas volume obtained from the mixture is $50 \%$ less voluminous than the gas yield observed with glucose. As a conclusion, phenol has an influence on glucose conversion and more precisely on the quantity of gas produced in these operating conditions. Phenol probably influences the intermediate products of glucose degradation because glucose is also totally removed from the mixture outflow.

Gas quantity is not the only parameter affected by the presence of phenol: TOC and residual phenol values obtained from the mixtures are higher than the sum of the values obtained from the solutions of each compound. Fig. 7 shows the values of TOC as function of the solution's composition at the same flow rate. For glucose solutions of $1 \mathrm{wt} \%$ the TOC is very low. On the contrary, for $1 \mathrm{wt} \%$ phenol solutions, the TOC value in the liquid phase is 10 times higher. If the TOC of the mixture was simply the sum of the other two values, the TOC would only be a little higher than the value of the phenol solution. As seen on Fig. 7 TOC value of 
the mixtures is higher, meaning that phenol interacts with the intermediate products of glucose degradation, therefore modifying the glucose degradation process. Similar results concerning TOC and residual phenols are obtained with the other two flow rates: at $0.982 \mathrm{~kg}$ $\mathrm{h}^{-1}$, the theoretical values of TOC and residual phenol would respectively be $5.45 \mathrm{~g} \mathrm{~L}^{-1}$ and $6.14 \mathrm{~g} \mathrm{~L}^{-1}$. The experimentally found values are higher: $6.96 \mathrm{~g} \mathrm{~L}^{-1}$ of TOC and $8.3 \mathrm{~g} \mathrm{~L}^{-1}$ of residual phenol. For the flow rate of $3.8 \mathrm{~kg} \mathrm{~h}^{-1}$, the experimental values are 1.5 higher than the theoretical sum: $6.1 \mathrm{~g} \mathrm{~L}^{-1}$ for the experimental TOC and $7.3 \mathrm{~g} \mathrm{~L}^{-1}$ for the experimental phenol. Other experiments were performed with various compositions of mixture solution considering a total weight of organic compounds equal to $2 \%$. As it was expected and in accordance with Yoshida et al. [23] who used a cellulose-lignin mixture in their operating conditions, the comparison of normalised yield gas as function of phenol fraction showed a non-linear profile. The influence of temperature was studied. Fig. 8 shows the influence of temperature on the TOC value for three different compositions of $2 \mathrm{wt} \%$ feed solutions. The initial TOC of these solutions were $7.3 \mathrm{mg} \mathrm{L}^{-1}$ for glucose, $7.7 \mathrm{mg} \mathrm{L}^{-1}$ for $0.1 \mathrm{wt} \%$ phenol and $8.3 \mathrm{mg} \mathrm{L}^{-1}$ for 0.25 wt $\%$ phenol. As for previous experiments, glucose concentration in outflow liquid phase equals to zero.

As shown in Fig. 7 for a glucose solution $(\mathbf{\Delta})$ the TOC is removed from the solution with a high efficiency regardless of the temperature. Glucose degradation depends on temperature: TOC removal increases from 82 to $91 \%$ when increasing the temperature from 450 to $500^{\circ} \mathrm{C}$. For the mixture containing $0.1 \mathrm{wt} \%$ of phenol (घ), TOC removal linearly increases from 75 to $94 \%$ with the temperature. In fact, TOC removal is only of $22 \%$ at $450^{\circ} \mathrm{C}$ but reaches $77 \%$ at $550^{\circ} \mathrm{C}$. On the contrary, the values of TOC removal dramatically decrease with $0.25 \mathrm{wt} \%$ of phenol in the mixture $(\diamond)$, unlike results with glucose. Fig. 8 shows that the temperature has an influence on the mineralisation's efficiency regardless of the composition, and that a small initial quantity of phenol changes the gasification behaviour of the solution. The residual 
phenol values also showed a profile close to the profiles observed with TOC values. The analytical method for residual phenol did not separate phenol molecules from their derivates (cresol, oligomers...). However, an estimation of the part of TOC represented by phenol (6 atoms of carbon) was calculated. The part of phenol in the experimental TOC value for the solution at $0.25 \mathrm{wt} \%$ of phenol $(\diamond)$ is around $20 \%$ whereas it is more than $50 \%$ in the other cases.

When adding a small amount of phenol to glucose solution, residual TOC and residual phenol are significantly increased, confirming the influence of phenol on glucose SCWG conversion. To understand the chemistry of phenol gasification, the reaction path from phenol to compounds with a higher molecular weight has to be considered; DiLeo et al. [29] report the formation of e.g. dibenzofuran and biphenyl from phenol. The compounds with a large conjugated electron system obtained in the SCWG process would form relatively stable free radicals and would act as a free radical scavenger. This would explain the reduced gasification of glucose in the presence of phenol. As above mentioned, no such compound could be found here. Still, in further experiments it has to be verified whether these compounds are to be found, formed or not. For example, it is possible that such compounds may stick to the reactor's wall.

On the other hand, studies on phenol oxidation mentioned in the introduction show that the free radical chemistry of phenols is complex. Also during oxidation, higher molecular weight compounds are found. The addition of an active free radical to phenol, as observed in SCWG and SCWO of phenol, should lead to a less reactive free radical, slowing down the free radical chain mechanism. Yet, this effect seems to be too low to explain the results presented here. Further investigations are necessary to clarify this point.

\section{Conclusion}


SCWG of glucose and/or phenol in diluted solutions was studied in a continuous flow reactor (25 MPa and $400-550^{\circ} \mathrm{C}$ ). The achieved comparison between solutions of only one compound and mixtures showed that the presence of phenol, even in a small amount in a glucose solution, decreases the conversion's efficiency. In our experiments, phenol is considered as an intermediate of lignin hydrolysis/gasification. The role played by phenol in glucose degradation can be correlated with the literature data related to the lignin influence on the SCWG of carbohydrates.

Phenol reduces hydrogen yield and particularly the total volume of gas from the conversion of glucose. Consequently, in the presence of phenol, the TOC and residual phenols of the liquid phase is higher. TOC removal dramatically decreases in presence of phenol in the mixture.

One possible explanation is that, similarly to studies on the influence of proteins [27, 42], phenol works as a free radical scavenger, which has to be proven in further experiments.

\section{References}

[1] A. Kruse, Hydrothermal biomass gasification, J. Supercritical Fluids 47 (2009) 391-399.

[2] A.A. Clifford, Reactions in supercritical water, Chimica Oggi 11 (1993) 36-37.

[3] F. Cansell, S. Rey, P. Beslin, Thermodynamic aspects of supercritical fluids processing: applications to polymers and wastes treatment, Revue de l'Institut Français du Pétrole 53 (1998) 71-98.

[4] R.W. Shaw, T.B. Brill, A.A. Clifford, C.A. Eckert, E.U. Franck, Supercritical water- a medium for chemistry, Chemical \& Engineering News 69 (1991) 26-39.

[5] P.E. Savage, S.G. Gopalan, T.I. Mizan, C.J. Martino, E.E. Brock, Reactions at supercritical conditions: applications and fundamentals, AIChE 41 (1995) 1723-1778. 
[6] W.L. Marshall, E.U. Franck, Ion product of water substance, $0-1000^{\circ} \mathrm{C}, 1-10,000$ bar new international formulation and its background, J. Physical \& Chemical Reference Data 10 (1981) 295-304.

[7] E.U. Franck, Thermophysical properties of supercritical fluids with special consideration of aqueous systems, Fluid Phase Equilibria 10 (1983) 211-222.

[8] A. Kruse, E. Dinjus, Hot compressed water as reaction medium and reactant. Properties and synthesis reactions, J. Supercritical Fluids 39 (2007) 362-380.

[9] J.W. Tester, A. Marrone, M.M. DiPippo, K. Sako, M.T. Reagan, T. Arias, W.A. Peters, Chemical reactions and phase equilibria of model halocarbons and salts in sub- and supercritical water (200-300 bar, 100-600 ${ }^{\circ}$ C), J. Supercritical Fluids 13 (1998) 225-240.

[10] S.E. Hunter, P.E. Savage, Recent advances in acid- and base-catalyzed organic synthesis in high-temperature liquid water, Chemical Engineering Science 22/23 (2004) 4903-4909.

[11] A. Kruse, E. Dinjus, Hot compressed water as reaction medium and reactant. 2. Degradation reactions, J. Supercritical Fluids 41 (2007) 361-379.

[12] D. Yu, M. Aihara, M.J. Antal, Hydrogen production by stream reforming glucose in supercritical water, Energy \& Fuels 7 (1993) 574-577.

[13] Y. Matsumura, T. Minowa, B. Potic, S.R.A. Kersten, W. Prins, W.P.M. van Swaaij, B. van de Beld, D.C. Elliott, G.G. Neuenschwander, A. Kruse, M.J. Antal, Biomass gasification in near- and super-critical water: status and prospects (review), Biomass \& Bioenergy 29 (2005) 269-292.

[14] D. Sutton, B. Kezlleher, J.R.H. Ross, Review of literature on catalysts for biomass gasification, Fuel Processing Technology 73 (2001) 155-173.

[15] J. Yanik, S. Ebale, A. Kruse, M. Saglam, M. Yüksel, Biomass gasification in supercritical water: II. Effect of catalyst, International J. Hydrogen Energy 33 (2008) 45204526. 
[16] I.G. Lee, M.S. Kim, S.K. Ihm, Gasification of glucose in supercritical water, Industrial \& Engineering Chemistry Research 41 (2002) 1182-1188.

[17] M. Watanabe, H. Inomata, K. Arai, Catalytic hydrogen generation from biomass (glucose and cellulose) with $\mathrm{ZrO}_{2}$ in supercritical water, Biomass \& Bioenergy 22 (2002) 405-410.

[18] T.M. Aida, Y. Sato, M. Watanabe, K. Tajima, T. Nonaka, H. Hattori and K. Arai, Dehydration of D-glucose in high temperature water at pressures up to $80 \mathrm{MPa}, \mathrm{J}$. Supercritical Fluids 40 (2007) 381-388.

[19] A. Sinağ, A. Kruse, V. Schwarzkopf, Key compounds of the hydropyrolysis of glucose in supercritical water in the presence of $\mathrm{K}_{2} \mathrm{CO}_{3}$, Industrial \& Engineering Chemistry Research 42 (2003) 3516-3521.

[20] A.K. Goodwin, G.L. Rorrer, Conversion of glucose to hydrogen-rich gas by supercritical water in a microchannel reactor, Industrial \& Engineering Chemistry Research 47 (2008) 4106-4114.

[21] M. Sasaki, T. Adschiri, K. Arai, Kinetics of cellulose conversion at $25 \mathrm{MPa}$ in sub- and supercritical water, AIChE 50 (2004)192-202.

[22] F.L.P. Resende, M.E. Neff, P.E. Savage, Noncatalytic gasification of cellulose in supercritical water, Energy \& Fuels 21 (2007) 3637-3643.

[23] T. Yoshida, Y. Matsumura, Gasification of cellulose, xylan and lignin mixtures in supercritical water, Industrial \& Engineering Chemistry Research 40 (2001) 5469-5474.

[24] M. Saisu, T. Sato, M. Watanabe, T. Adschiri, K. Arai, Conversion of lignin with supercritical water-phenol mixtures, Energy \& Fuels 17 (2003) 922-928.

[25] T. Yoshida, Y. Oshima, Y. Matsumura, Gasification of model compounds and real biomass in supercritical water, Biomass \& Bioenergy 26 (2004) 71-78.

[26] F.L.P. Resende, S.A. Fraley, M.J. Berger, P.E. Savage, Noncatalytic gasification of lignin in supercritical water, Energy \& Fuels 22 (2008) 1328-1334.

[27] J. Yanik, S. Ebale, A. Kruse, M. Saglam, M. Yüksel, Biomass gasification in supercritical water: Part 1. Effect of the nature of biomass, Fuel 86 (2007) 2410-2415. 
[28] G.J. DiLeo, M.E. Neff, S. Kim, P.E. Savage, Supercritical water gasification of phenol and glycine as models for plant and protein biomass, Energy \& Fuels 22 (2008) 871-877.

[29] G.J. DiLeo, M.E. Neff, P.E. Savage, Gasification of guaiacol and phenol in supercritical water, Energy \& Fuels 21 (2007) 2340-2345.

[30] A. Kruse, A. Gawlik, Biomass conversion in water at $330-410^{\circ} \mathrm{C}$ and $30-50 \mathrm{MPa}$. Identification of key compounds for indicating different chemical reaction pathways, Industrial \& Engineering Chemistry Research 42 (2003) 267-279.

[31] E. Weiss, K. Groenen-Serrano, A. Savall, A comparison of electrochemical degradation of phenol on boron doped diamond and lead dioxide electrodes, J. Applied Electrochemistry 38 (2008) 329-337.

[32] G. Busca, S. Berardinelli, C. Resini, L. Arrighi, Technologies for the removal of phenol from fluid streams: A short review of recent developments, J. Hazardous Materials 160 (2008) 265-288.

[33] T.T. Thornton, P.E. Savage, Phenol oxidation pathways in supercritical water, Industrial \& Engineering Chemistry Research 31 (1992) 2451-2456.

[34] S. Gopalan, P.E. Savage, A reaction network for phenol oxidation in supercritical water, AIChE 41 (1995) 1864-1873.

[35] M. Krajnic, J. Levec, On the kinetics of phenol oxidation in supercritical water, AIChE 42 (1996) 1977-1983.

[36] J.T. Henrikson, Z. Chen, P.E. Savage, Inhibition and acceleration of phenol oxidation by supercritical water, Industrial \& Engineering Chemistry Research 42 (2003) 6303-6309.

[37] J.T. Henrikson, P.E. Savage, Potential explanation for the inhibition and acceleration of phenol SCWO by water, Industrial \& Engineering Chemistry Research 43 (2004) 4841-4847. 
[38] J.A. Onwudili, P.T. Williams, Reaction mechanisms for the decomposition of phenantrene and naphtalene under hydrothermal conditions, J. Supercritical Fluids 39 (2007) $399-408$.

[39] A. Sinăg, A. Kruse, V. Schwarzkopf, Formation and degradation pathways of intermediate products formed during the hydropyrolysis of glucose as a model substance for wet biomass in a tubular reactor, Engineering in Life Science 3 (2003) 469-473.

[40] B.M. Kabyemela, T. Adschiri, R.M. Malaluan, K.Arai, Kinetics of glucose epimerization and decomposition in subcritical and supercritical water, Industrial \& Engineering Chemistry Research 36 (1997) 1552-1558.

[41] M. Watanabe, F. Bayer, A. Kruse, Oil formation from glucose with formic acid and cobalt catalyst in hot-compressed water, Carbohydrate Research 341 (2006) 2891-2900. [42] A. Kruse, P. Maniam, F. Spieler, Influence of proteins on the hydrothermal gasification and liquefaction of biomass. 2. Model compounds, Industrial \& Engineering Chemistry Research 46 (2007) 87-96. 


\section{Captions}

Figure 1: Scheme of the apparatus with nitrogen supply (A), feed tank (B), high pressure pump (C), preheater (D), reactor (E), cooler (D), pressure control unit (E), phase separation (F), wet gas meter (G) and gas sampling $(\mathrm{H})$.

Figure 2: Influence of glucose concentration on the normalized gas yield during the SCWG at $500^{\circ} \mathrm{C}, 25 \mathrm{MPa}$ and $1.385 \mathrm{~kg} \mathrm{~h}^{-1}$, in presence of $0.2 \mathrm{wt} \%$ of $\mathrm{KHCO}_{3}$.

Figure 3: Influence of glucose concentration on gas composition during SCWG at $500^{\circ} \mathrm{C}, 25$ $\mathrm{MPa}$ and $1.385 \mathrm{~kg} \mathrm{~h}^{-1}$, in presence of $0.2 \mathrm{wt} \%$ of $\mathrm{KHCO}_{3}$.

Figure 4: Influence of residence time on the residual phenol during the $\mathrm{SCWG}$ at $500^{\circ} \mathrm{C}, 25$ $\mathrm{MPa}$, for a $1 \mathrm{wt} \%$ phenol solution in presence of $0.2 \mathrm{wt} \%$ of $\mathrm{KHCO}_{3}$.

Figure 5: Influence of temperature on the residual phenol for a residence time of 0.06 min during the SCWG at $25 \mathrm{MPa}$, for a $1 \mathrm{wt} \%$ phenol solution in presence of $0.2 \mathrm{wt} \%$ of $\mathrm{KHCO}_{3}$.

Figure 6: Comparison of theoretical sum of gas volume obtained during the SCWG of solutions containing $1 \mathrm{wt} \%$ glucose and $1 \mathrm{wt} \%$ phenol and the experimental gas volume obtained for a solution containing $1 \mathrm{wt} \%$ glucose +1 wt $\%$ phenol. $\mathrm{P}=25 \mathrm{MPa}, \mathrm{T}=500^{\circ} \mathrm{C}$, flow rate $=1.385 \mathrm{~kg} \mathrm{~h}^{-1}$ and $\mathrm{KHCO}_{3}=0.2 \mathrm{wt} \%$.

Figure 7: Comparison of theoretical sum of TOC obtained during the SCWG of solutions containing $1 \mathrm{wt} \%$ glucose and $1 \mathrm{wt} \%$ phenol and the experimental gas volume obtained for a solution containing $1 \mathrm{wt} \%$ glucose +1 wt $\%$ phenol. $\mathrm{P}=25 \mathrm{MPa}, \mathrm{T}=500^{\circ} \mathrm{C}$, flow rate $=1.385$ $\mathrm{kg} \mathrm{h}^{-1}$ and $\mathrm{KHCO}_{3}=0.2 \mathrm{wt} \%$.

Figure 8: Influence of temperature on TOC values for 3 compositions of mixture solutions during the SCWG at $25 \mathrm{MPa}, 2.19 \mathrm{~kg} \mathrm{~h}^{-1}$ and in presence of $0.2 \mathrm{wt} \%$ of $\mathrm{KHCO}_{3}$. Solutions contain 2 wt $\%$ of organic compound, with various proportion of phenol: $\boldsymbol{\Delta} 0 \%$; $0.1 \%$ and $\bullet 0.25 \%$. 
Fig. 1:

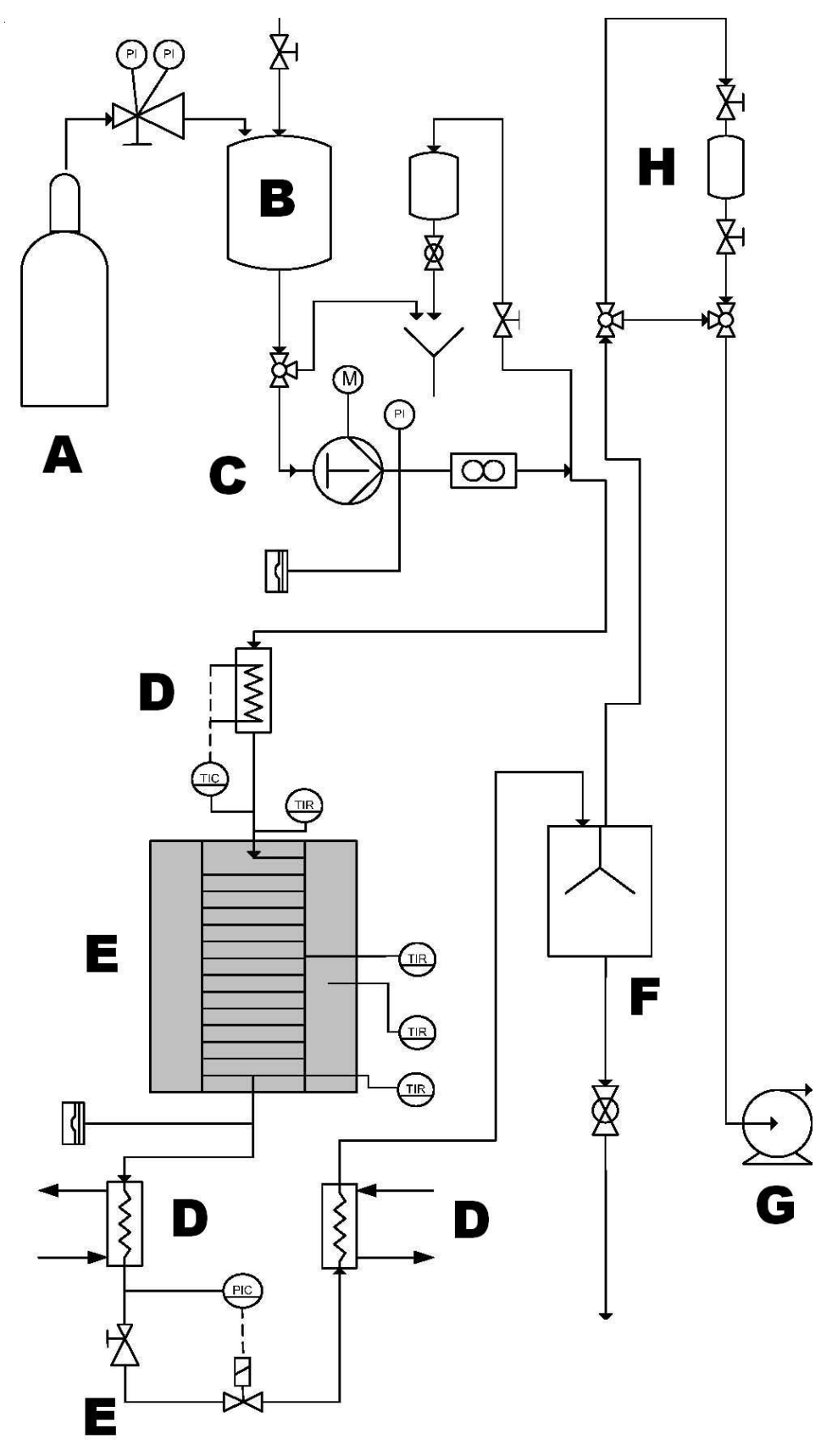


Fig. 2:

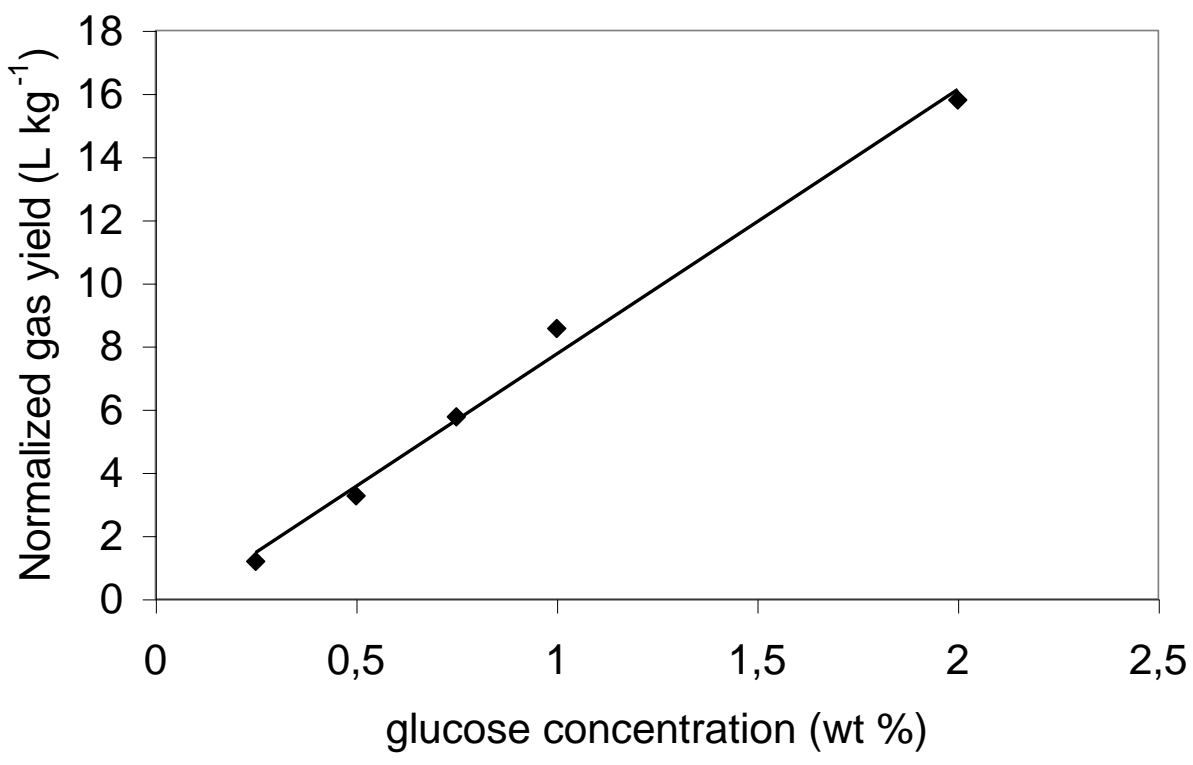


Fig. 3:

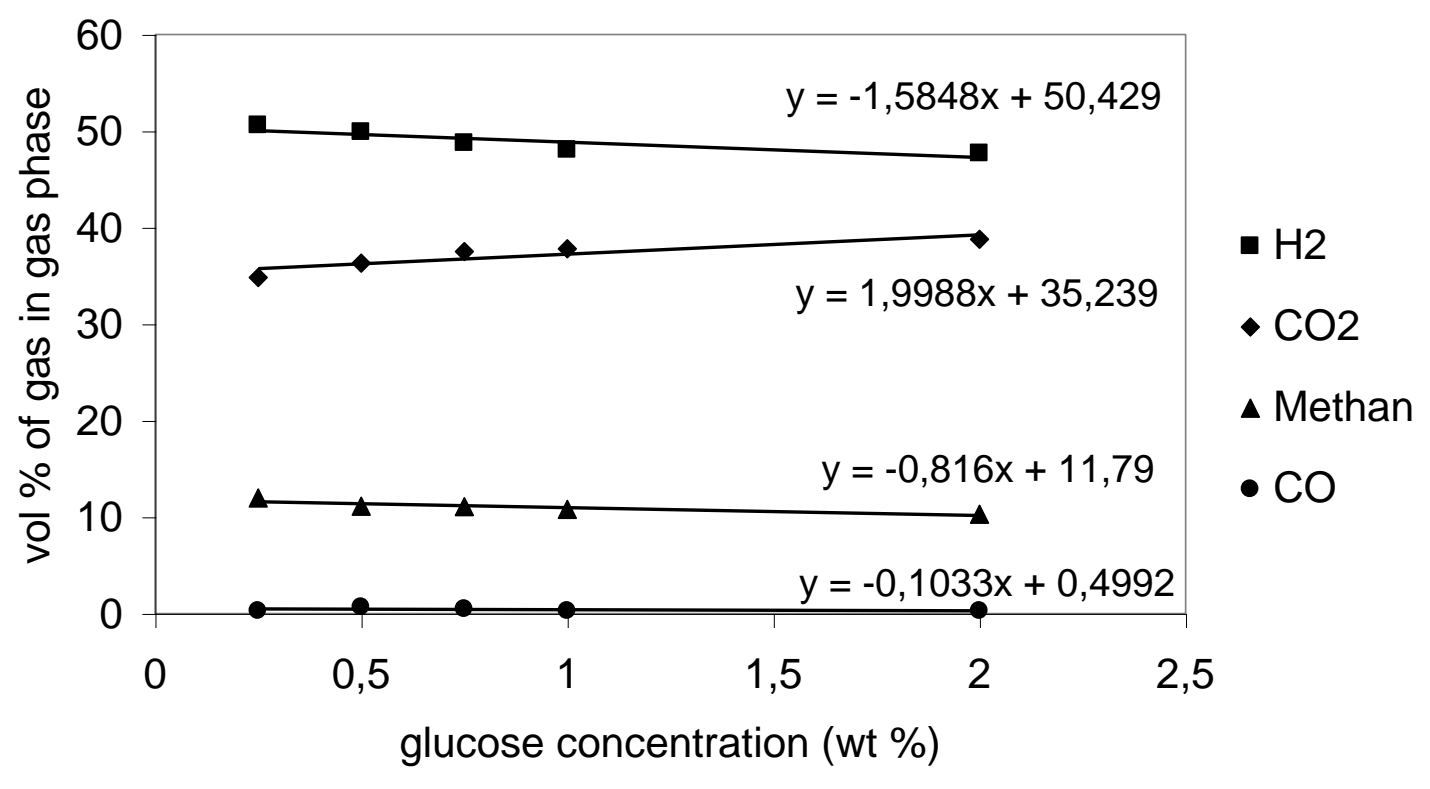


Fig. 4:

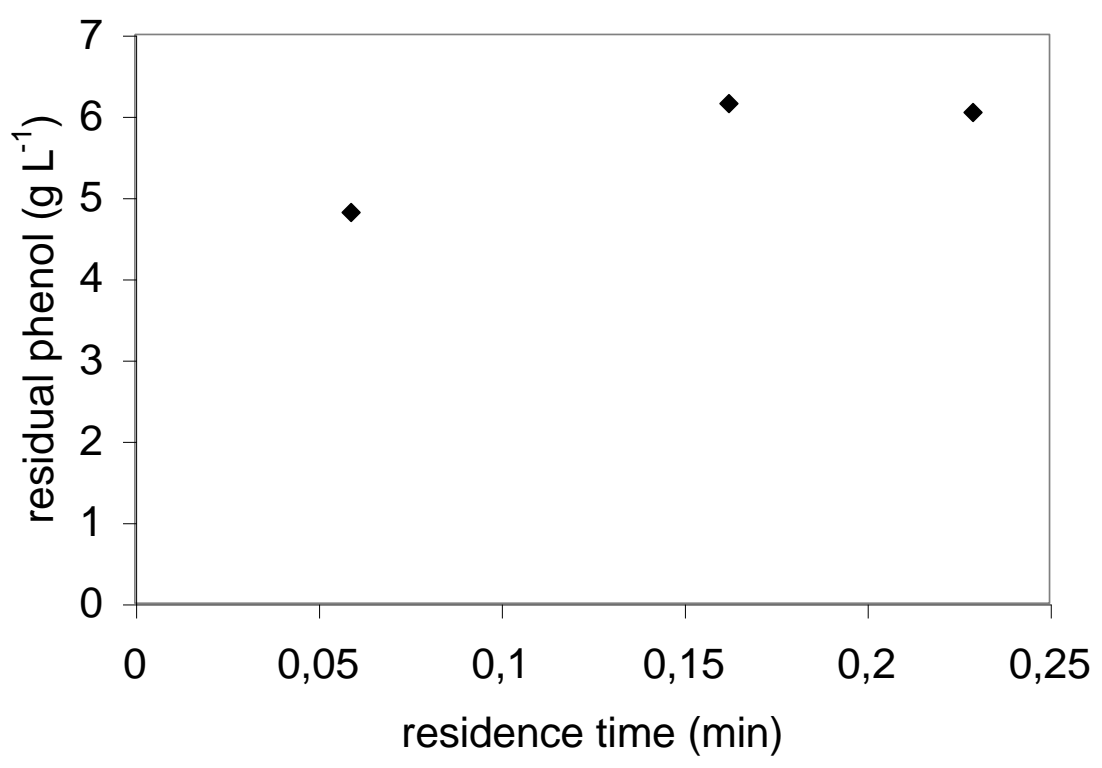


Fig. 5:

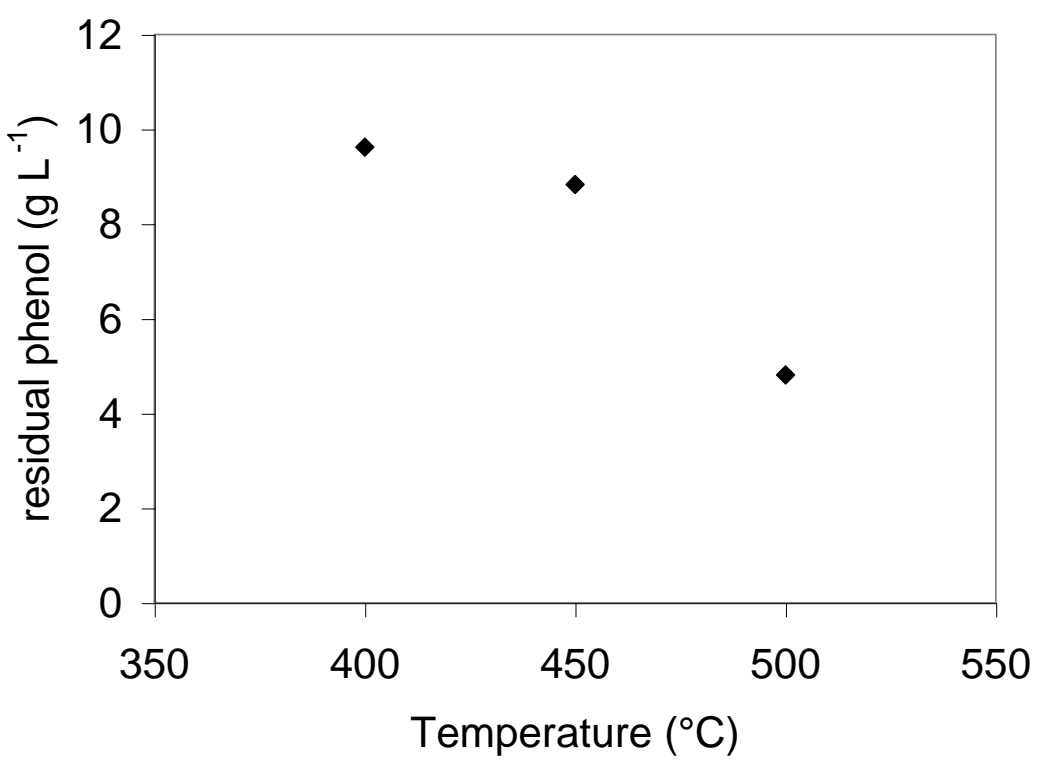


Fig. 6:

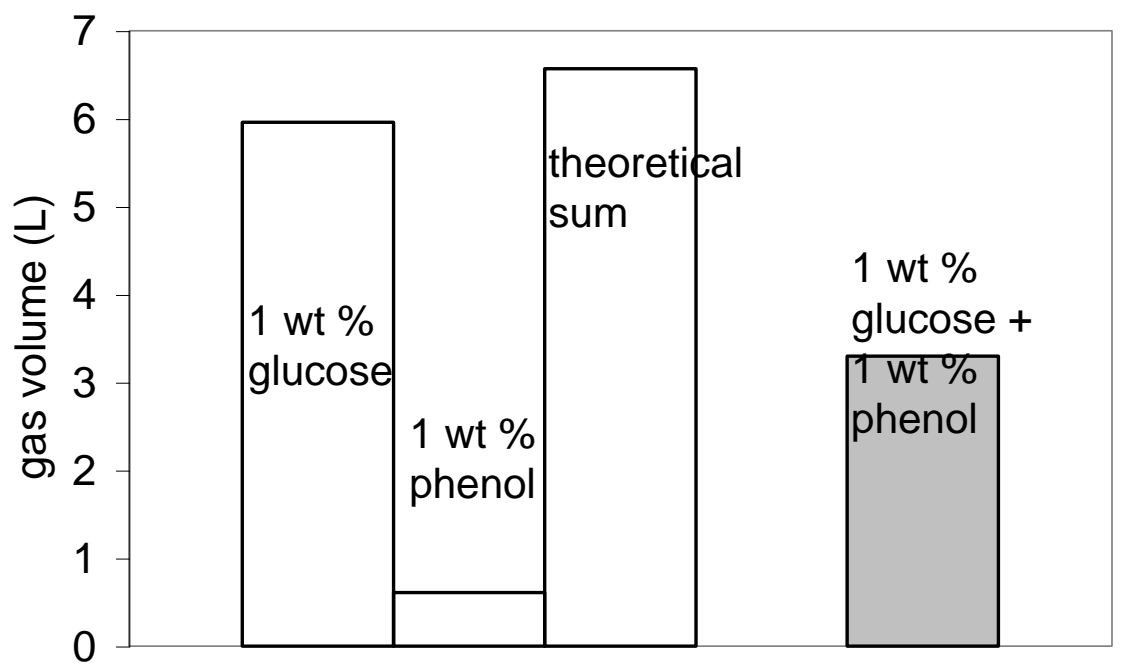


Fig. 7:

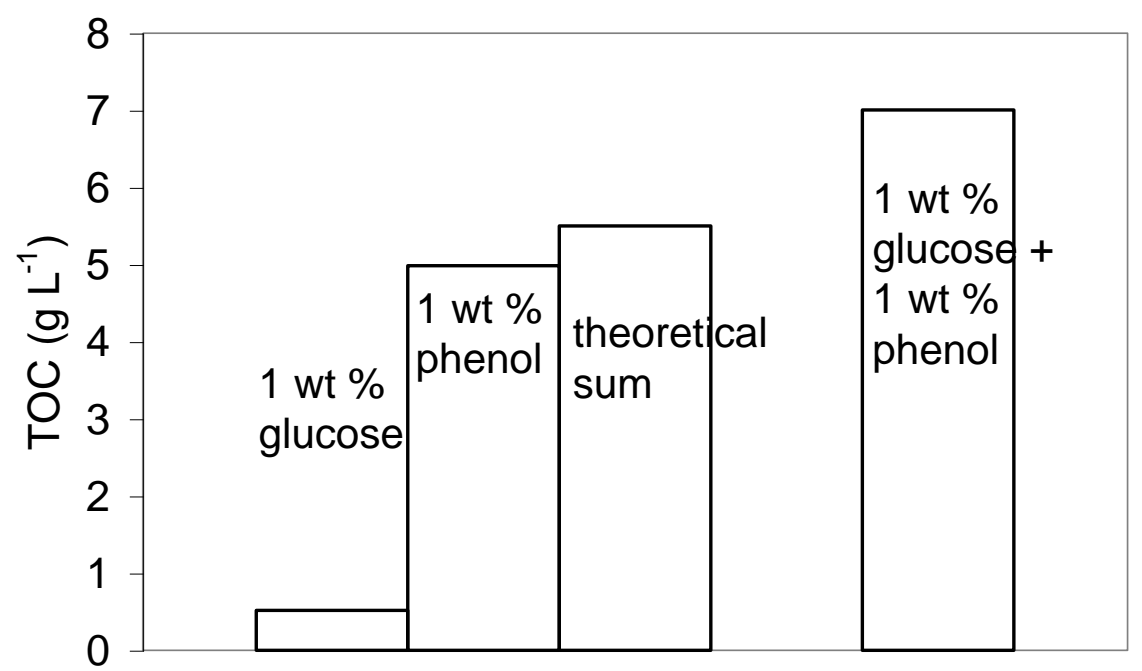


Fig. 8:

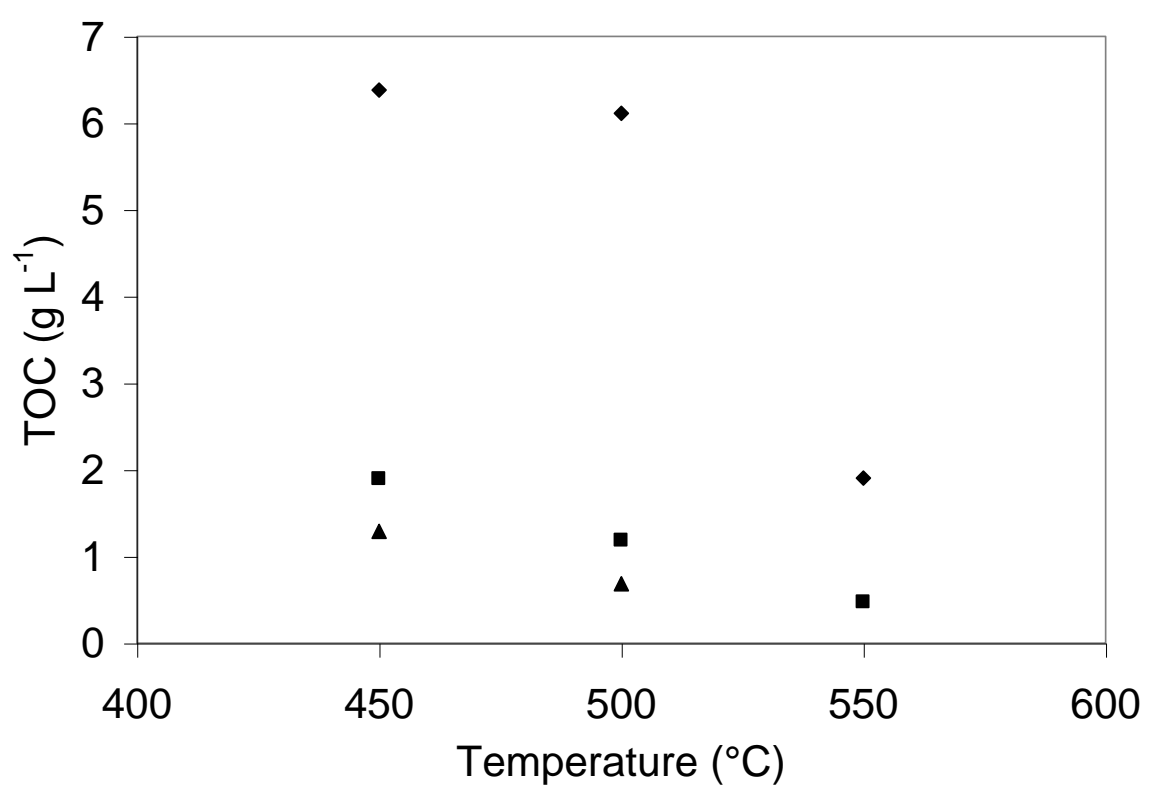

